\title{
Model Matematika Dinamika Bahasa Minang dan Bahasa Indonesia
}

\author{
Nadiatur Rahma ${ }^{\# 1}$, Muhammad Subhan ${ }^{* 2}$, Yusmet Rizal ${ }^{* 3}$ \\ ${ }^{\#}$ Student of Mathematics Department Universitas Negeri Padang, Indonesia \\ *Lecturers of Mathematics Department Universitas Negeri Padang, Indonesia \\ ${ }^{1}$ nadiatur.rahma1994@gmail.com \\ ${ }^{2} 13$ subhandgmail.com \\ ${ }^{3} 13$ yusmet abdurrahmandyahoo.id
}

\begin{abstract}
This article discussed the mathematical model of the dynamics of Minang language and Indonesia language to describe the language extinction. This research use literature study. Model of the dynamics of Minang language and Indonesia language in form of non linier diferensial equation's system. From the results of the analysis obtained three equilibrium. The equilibrium of Minang language extinction is stable. The equilibrium of Indonesia language extinction is not stable. The equilibrium of free language extinction is stable if volatility level of both language is low. Howover, not stable if volatility level of both language is high. At the end, there will be done a kind of simulation is performed to illustrate the analysis results obtained.
\end{abstract}

Keywords - dynamic, language extinction, mathematical model, equilibrium, stability

\begin{abstract}
Abstrak - Pada artikel ini dibahas model matematika dinamika bahasa Minang dan bahasa Indonesia untuk menggambarkan kepunahan bahasa. Penelitian ini menggunakan studi kepustakaan. Model dinamika bahasa Minang dan bahasa Indonesia berbentuk sistem persamaan diferensial non linier. Dari hasil analisis diperoleh tiga titik kesetimbangan. Titik keseimbangan kepunahan bahasa Minang bersifat stabil. Titik keseimbangan kepunahan bahasa Indonesia bersifat tidak stabil. Titik keseimbangan bebas kepunahan bahasa bersifat stabil. jika tingkat volatility kedua bahasa rendah. Namun, tidak bersifat stabil jika tingkat volatility kedua bahasa tinggi. Pada bagian akhir, dilakukan simulasi untuk mengilustrasikan hasil analisis yang diperoleh.
\end{abstract}

Kata Kunci - dinamika,kepunahan bahasa, model matematika, titik kesetimbangan, kestabilan

\section{PENDAHULUAN}

Bahasa adalah suatu alat komunikasi. Suatu bahasa yang dikenal sebagai sarana untuk berkomunikasi dalam bersosialisasi, mengalami dinamika perkembangan dan perubahan dari waktu ke waktu[4].

Sama seperti spesies biologi, bahasa juga memiliki siklus hidup dari lahir, berkembang, dan kematian. Ada sekitar 6000-7000 bahasa saat ini digunakan di dunia. Namun, 50-90\% dari mereka menghadapi kepunahan di abad ke-21 sebagai hasil dari persaingan bahasa[5]. Ethnoloque merupakan suatu terbitan web dan cetak SIL International (The Summer Institute of Linguistics), suatu lembaga jasa linguistic nasrani yang meneliti bahasa yang kurang dikenal, dengan tujuan utama menerbitkan terjemahan Alkitab dalam bahasa tersebut. Terdapat 473 bahasa yang tercantum dalam Ethnoloque, diklafikasikan sebagai hampir punah, yang didefinisikan sebagai hanya penutur asli yang masih hidup. Daya hidup suatu bahasa adalah "use of linguistic system by an unisolated community of native speakers" [3]. Jika suatu bahasa secara terusmenerus mengalami pengurangan jumlah penutur sehingga pada akhirnya kehilangan atau kehabisan jumlah penutur asli, bahasa itu sudah jelas bernasib punah.

Pergeseran bahasa kadang-kadang mengacu kepada kepunahan bahasa. Hal ini terjadi manakala guyup (masyarakat) bergeser ke bahasa baru secara total sehingga bahasa terdahulu tidak dipakai lagi. Pergeseran bahasa (language shift) menyangkut masalah penggunaanya bahasa oleh sebuah penutur atau sekelompok penutur yang biasa terjadi sebagai akibat perpindahan dari satu masyarakat tutur ke masyarakat tutur lain [2].

Pada penelitian ini, penulis melihat frekuensi penutur bahasa Minang dan bahasa Indonesia dalam satuan waktu. Selain itu, model ini juga memperhitungkan tingkat pergeseran dari satu bahasa ke bahasa. Selanjutnya setelah 
membentuk model, akan dilakukan analisis dan interpretasi hasil model. Sehingga penelitian ini diberi judul "Model Matematika Dinamika Bahasa Minang dan Bahasa Indonesia".

\section{METODE}

Penelitian ini adalah penelitian dasar. Adapun metode yang digunakan adalah studi kepustakaan dengan menganalisis tori-teori yang relevan terhadap permasalahan yang dibahas. Langkah-langkah untuk mendapatkan jawaban dari permasalahan yaitu:

1. Mempelajari teori-teori yang relevan dengan permasalahan model matematika dinamika bahasa Minang dan bahasa Indonesia.

2. Membentuk model matematika dinamika bahasa Minang dan bahasa Indonesia.

3. Menganalisis model matematika dinamika bahasa Minang dan bahasa Indonesia.

4. Menginterpretasi hasil analisis dari model.

\section{HASIL DAN PEMBAHASAN}

\section{A. Model Matematika Dinamika Bahasa Minang dan Bahasa Indonesia}

Berdasarkan langkah-langkah dalam membentuk model matematika, langkah pertama yang dilakukan adalah menyatakan problem pada dunia nyata ke bentuk problem matematika. Langkah ini dilakukan dengan menentukan faktor yang dianggap penting atau sesuai dengan permasalahan. Meliputi identifikasi variabel, parameter dan membentuk hubungan antar variabel dan parameter tersebut.

Adapun variabel dan parameter yang digunakan adalah sebagai berikut:

Variabel:

$n_{X}=$ frekuensi bertutur bahasa Minang (per satuan waktu)

$n_{Y}=$ frekuensi bertutur bahasa Indonesia (per satuan waktu)

Dan parameter yang digunakan adalah:

$P_{Y X}=$ Tingkat pergeseran dari bahasa Indonesia ke bahasa Minang

$P_{X Y}=$ Tingkat pergeseran dari bahasa Minang ke bahasa Indonesia

$s_{X} \quad=$ Tingkat status sosial dan ekonomi bahasa Minang

$s_{Y}=$ Tingkat status sosial dan ekonomi bahasa Indonesia

$a \quad=$ Tingkat volatility bahasa Minang

$b \quad=$ Tingkat volatility bahasa Indonesia

c = Tingkat kontak

Dilakukan penyederhanaan masalah dengan menggunakan asumsi sebagai berikut:
1. Setiap individu hanya berbicara salah satu dari dua bahasa : $n_{X}+n_{Y}=1$. Karena setiap individu pasti berkomunikasi menggunakan bahasa Minang atau bahasa Indonesia.

2. Dalam model ini, hanya memperhitungkan bahasa Minang dan bahasa Indonesia karena akan dilihat pengaruh bahasa daerah dengan bahasa persatuan .

3. Adanya status sosial dan ekonomi masing-masing bahasa yang dituturkan, dilambangkan dengan $s_{X}$ dan $s_{Y}$, dimana $s_{X}+s_{Y}=1$. Karena hanya ada satu bahasa yang akan memiliki status sosial yang lebih tinggi yang dilihat dari pekerjaan, pendidikan, dan ekonomi seseorang yaitu status sosial ekonomi bahasa Minang atau bahasa Indonesia. Dimana status sosial ekonomi bahasa Minang lebih rendah dari bahasa Indonesia berarti $s_{X}<s_{Y}$. Karena saat ini bahasa Indonesia lebih mendukung pekerjaan, pendidikan dan ekonomi seseorang dibandingkan bahasa Minang.

4. Tingkat Volatility adalah perubahan frekuensi bertutur bahasa. Jika $a, b=1$ maka kondisi netral, tidak terjadi perubahan frekuensi bertutur bahasa. Volatility besar untuk $a, b>1$ dimana perubahan frekuensi bertutur bahasa lebih besar dari kondisi netral sehingga akan sering terjadi pergeseran bahasa. Volatility rendah untuk $a, b<1$ dimana perubahan frekuensi bertutur bahasa rendah dari kondisi netral, sehingga bahasa memiliki ketahanan yang besar dan tidak menimbulkan pergeseran bahasa.

Berdasarkan asumsi-asumsi, variabel dan parameter maka dapat dibentuk midel matematika dinamika bahasa Minang dan bahasa Indonesia sebagai berikut:

$\frac{d n_{x}}{d t}=n_{x} P_{Y X}\left(n_{x}, s_{X}\right)-n_{y} P_{X Y}\left(n_{y}, s_{Y}\right)$

$\frac{d n_{y}}{d t}=n_{y} P_{X Y}\left(n_{y}, s_{Y}\right)-n_{x} P_{Y X}\left(n_{x}, s_{X}\right)$

Dimana

$n_{X}+n_{Y}=1$

$0 \leq n_{X}, n_{Y} \leq 1$

$0 \leq s_{X}, s_{Y} \leq 1$

$s_{X}+s_{Y}=1$

$P_{X Y}\left(n_{Y}, s_{Y}\right)=c n_{Y}^{b} s_{y}$

$P_{Y X}\left(n_{X}, s_{X}\right)=c n_{X}^{a} s_{X}$

Sehingga pers (2) dan (3) menjadi

$\frac{d n_{x}}{d t}=n_{Y} c n_{X}^{a} s_{X}-n_{X} c n_{Y}^{b} s_{y}$

$\frac{d n_{y}}{d t}=n_{X} c n_{Y}^{b} s_{Y}-n_{Y} c n_{X}^{a} s_{X}$

B. Analisis Model Matematika Dinamika Bahasa Minang dan Bahasa Indonesia 
1) Titik tetap model: Analisis titik tetap pada sistem persamaan diferensial sering digunakan untuk menentukan solusi yang tidak berubah terhadap waktu. Titik tetap model dapat ditentukan ketika $\frac{d n_{X}}{d t}=0, \frac{d n_{Y}}{d t}=0$. Sehingga diperoleh:

$n_{Y} P_{Y X}\left(n_{X}, s_{X}\right)-n_{X} P_{X Y}\left(n_{Y}, s_{Y}\right)=0$

$n_{X} P_{X Y}\left(n_{Y}, s_{Y}\right)-n_{Y} P_{Y X}\left(n_{X}, s_{X}\right)=0$

Selanjutnya dari persamaan (5) dan (6) dicari titik tetap sehingga diperoleh titik tetap sebagai berikut:

a) Titik tetap kepunahan bahasa Indonesia $\left(T_{1}\right)$

Titik tetap $T_{1}$ merupakan suatu kondisi dimana kepunahan bagi bahasa Indonesia karena semua orang bertutur menggunakan bahasa Minang. Dari pers (5) disubtitusikan $n_{Y}=0$ dan diperoleh $n_{X}=1$. Jadi, titik tetap kepunahan bahasa Indonesia yaitu :

$T_{1}\left(x_{1}{ }^{*}, y_{1}{ }^{*}\right)=(1,0)$

b) Titik Tetap Kepunahan Bahasa Minang $\left(T_{2}\right)$

Titik tetap $T_{2}$ merupakan suatu kondisi dimana kepunahan bagi bahasa Minang karena semua orang bertutur menggunakan bahasa Indonesia. Dari pers (5) disubtitusikan $n_{X}=0$ dan diperoleh $n_{Y}=1$. Jadi, titik tetap kepunahan bahasa Minang yaitu:

$T_{2}\left(x_{2}{ }^{*}, y_{2}{ }^{*}\right)=(0,1)$

c) Titik Tetap Bebas Kepunahan $\left(T_{3}\right)$

Titik tetap $T_{3}$ merupakan suatu kondisi dimana bahasa Minang dan bahasa Indonesia dapat hidup berdampingan. $T_{3}$ diperoleh dari persamaan (5)

$n_{Y} c n_{X}^{a} s_{X}-n_{X} c n_{Y}^{b} s_{Y}=0$ sehingga

$n_{X}=\left(\frac{s_{Y}\left(n_{Y}\right)^{b-1}}{s_{X}}\right)^{\frac{1}{a-1}}$

Sehingga diperoleh $T_{3}$

$x_{3}{ }^{*}=\left(\frac{s_{Y}\left(n_{Y}\right)^{b-1}}{s_{X}}\right)^{\frac{1}{a-1}}$

$y_{3}{ }^{*}=n_{Y}$

Jadi, titik tetap bebas kepunahan bahasa $\left(T_{3}\right)$ adalah :

$T_{3}\left(x_{3}{ }^{*}, y_{3}{ }^{*}\right)=\left(\left(\frac{s_{Y}\left(n_{Y}\right)^{b-1}}{s_{X}}\right)^{\frac{1}{a-1}}, n_{Y}\right)$

Diketahui bahwa $n_{X}+n_{Y}=1$ sehingga

$\left(\frac{s_{Y}}{s_{X}}\right)^{\frac{1}{a-1}} n_{Y}^{\frac{b-1}{a-1}}+n_{Y}=1$

Karena pers (7) sulit disederhanakan jika $a \neq b$ maka dilakukan pemisalan dimana $a=b$ dan $a, b \neq 1$, sehingga diperoleh

$n_{Y}\left[\left(\frac{s_{Y}}{s_{X}}\right)^{\frac{1}{a-1}}+1\right]=1$ diperoleh

$n_{Y}=\frac{1}{\left(\frac{s_{Y}}{s_{X}}\right)^{\frac{1}{a-1}}+1}$

Diketahui bahwa $s_{X}<s_{Y}$, maka diperoleh 2 kasus yaitu sebagai berikut :
- $n_{Y}>n_{X}$ jika $a<1$

- $n_{Y}<n_{X}$ jika $a>1$.

Selanjutnya, akan dibuktikan titik $\mathrm{T}_{3}$ ada

Titik $\mathrm{T}_{3}$ ada jika $0<\left(\frac{s_{Y}}{s_{X}}\right)^{\frac{1}{a-1}} n_{Y}<1$

Akan dibuktikan $\left(\frac{s_{Y}}{s_{X}}\right)^{\frac{1}{a-1}} n_{Y}>0$ dimana $a \neq 1$

Bukti :

$\left(\frac{s_{Y}}{s_{X}}\right)^{\frac{1}{a-1}} n_{Y}>0$

$n_{Y}>0$

Akan dibuktikan $\left(\frac{s_{Y}}{s_{X}}\right)^{\frac{1}{a-1}} n_{Y}<1$ dimana $a \neq 1$

Bukti :

$\left(\frac{s_{Y}}{s_{X}}\right)^{\frac{1}{a-1}} n_{Y}<1$

$0<n_{Y}<\left(\frac{s_{Y}}{s_{X}}\right)^{\frac{1}{1-a}}$

Subtitusi syarat titik $\mathrm{T}_{3}$ ada ke pers (7) sehingga diperoleh

$0<\frac{1}{\left(\frac{s_{Y}}{s_{X}}\right)^{\frac{1}{a-1}}+1}<\left(\frac{s_{Y}}{s_{X}}\right)^{\frac{1}{1-a}}$

Jadi, titik $\mathrm{T}_{3}$ ada jika $0<\frac{1}{\left(\frac{s_{Y}}{s_{X}}\right)^{\frac{1}{a-1}}+1}<\left(\frac{s_{Y}}{s_{X}}\right)^{\frac{1}{1-a}}$ dengan syarat $a \neq 1$.

2) Analisis Kestabilan Titik Tetap Model Matematika Dinamika Bahasa Minang dan Bahasa Indonesia: Untuk melihat kestabilan dari titik tetap sistem dapat ditentukan berdasarkan nilai-nilai eigen dari matriks Jacobinya.

a) Kestabilan Titik Kesetimbangan Kepunahan Bahasa Indonesia

Definisi 1 [1] (Matriks Jacobian)

$J(f(x))=\left(\begin{array}{cccc}\frac{\partial f_{1}}{\partial x_{1}} & \frac{\partial f_{1}}{\partial x_{2}} & \cdots & \frac{\partial f_{1}}{\partial x_{n}} \\ \frac{\partial f_{2}}{\partial x_{1}} & \frac{\partial f_{2}}{\partial x_{2}} & \cdots & \frac{\partial f_{2}}{\partial x_{n}} \\ \vdots & \vdots & \ddots & \vdots \\ \frac{\partial f_{n}}{\partial x_{1}} & \frac{\partial f_{n}}{\partial x_{2}} & \cdots & \frac{\partial f_{n}}{\partial x_{n}}\end{array}\right)$

Untuk menentukan nilai eigen dari matriks Jacobian tersebut bisa dilakukan dengan menyelesaikan persamaan $\operatorname{det}(\lambda I-J)=0$.

Matriks Jacobian untuk titik kesetimbangan $T_{1}$ adalah:

$J\left(T_{1}\right)=\left(\begin{array}{cc}0 & c s_{X} \\ 0 & -c S_{X}\end{array}\right)$

Untuk menentukan nilai eigen dari matriks Jacobian tersebut dapat dilakukan dengan menyelesaikan persamaan $\operatorname{det}\left(\lambda I-J\left(T_{1}\right)\right)=0$.

$\left|\begin{array}{cc}\lambda & -c s_{X} \\ 0 & \lambda+c s_{X}\end{array}\right|=0$ 
Diperoleh nilai eigen sebagai berikut:

$\lambda_{1}=0$

$\lambda_{2}=-c s_{X}$

Karena hanya $\lambda_{2}$ bernilai negatif dan $\lambda_{1}=0$ maka belum bisa dikatakan titik tetap $T_{1}$ stabil. Oleh karena itu, akan dilakukan simulasi titik tetap $T_{1}$.

b) Kestabilan Titik Kesetimbangan Kepunahan Bahasa Minang

Matriks Jacobian untuk titik kesetimbangan $T_{2}$ adalah:

$J\left(T_{2}\right)=\left(\begin{array}{cc}-c S_{Y} & 0 \\ c S_{Y} & 0\end{array}\right)$

Untuk menentukan nilai eigen dari matriks Jacobian tersebut dapat dilakukan dengan menyelesaikan persamaan $\operatorname{det}\left({ }^{\prime} I-J\left(T_{2}\right)\right)=0$.

$\left|\begin{array}{cc}\lambda+c s_{Y} & 0 \\ c s_{Y} & 0\end{array}\right|=0$

Diperoleh nilai eigen sebagai berikut:

$\lambda_{1}=0$

$\lambda_{2}=-c s_{Y}$

Karena hanya $\lambda_{2}$ bernilai negatif dan $\lambda_{1}=0$ maka belum bisa dikatakan titik tetap $T_{2}$ stabil. Oleh karena itu, akan dilakukan simulasi titik tetap $T_{2}$.

c) Kestabilan Titik Kesetimbangan Bebas Kepunahan

Titik tetap $T_{3}=\left(x_{3}{ }^{*}, y_{3}{ }^{*}\right)=\left(\left(\frac{s_{Y}\left(n_{Y}\right)^{b-1}}{s_{X}}\right)^{\frac{1}{a-1}}, n_{Y}\right)$ dimana

$a, b \neq 1$ dan $a=\mathrm{b}$

Sehingga diperoleh $T_{3}=\left(x_{3}{ }^{*}, y_{3}{ }^{*}\right)=\left(\left(\frac{s_{Y}}{s_{X}}\right)^{\frac{1}{a-1}} n_{Y}, n_{Y}\right)$

Matriks Jacobi di titik tetap

$T_{3}=\left(x_{3}{ }^{*}, y_{3}{ }^{*}\right)=\left(\left(\frac{s_{Y}}{s_{X}}\right)^{\frac{1}{a-1}} n_{Y}, n_{Y}\right)$ adalah

$J\left(T_{3}\right)=\left(\begin{array}{ll}n_{Y} c s_{X} n_{X}{ }^{a-1} a-c s_{Y} n_{Y}{ }^{a} & c s_{X} n_{X}{ }^{a}-n_{X} c s_{Y} n_{Y}{ }^{a-1} a \\ c s_{Y} n_{Y}^{a}-n_{Y} c s_{X} n_{X}^{a-1} a & n_{X} c s_{Y} n_{Y}^{a-1} a-c s_{X} n_{X}{ }^{a}\end{array}\right)$

Dimana $n_{X}=\left(\frac{s_{Y}}{s_{X}}\right)^{\frac{1}{a-1}} n_{Y}$

Untuk menentukan nilai eigen dari matriks Jacobian tersebut dapat dilakukan dengan menyelesaikan persamaan $\operatorname{det}\left(\lambda I-J\left(T_{3}\right)\right)=0$.

$$
\left|\begin{array}{cc}
\lambda-n_{Y} c s_{X}<_{X}{ }^{a-1} p+c s_{Y} n_{Y}{ }^{a} & -c s_{X} n_{X}{ }^{a}+n_{X} c s_{Y} n_{Y}{ }^{a-1} a \\
-c s_{Y} n_{Y}{ }^{a}+n_{Y} c s_{X} n_{X}{ }^{a-1} a & \lambda-n_{X} c s_{Y} n_{Y}{ }^{a-1} a+c s_{X} n_{X}{ }^{a}
\end{array}\right|=0
$$

Untuk memperoleh nilai eigen maka $\operatorname{det}\left(\lambda I-J\left(T_{3}\right)\right)=0$. Diperoleh persamaan karakteristiknya sebagai berikut:

$\lambda^{2}+\lambda a_{1}+a_{2}=0$

Dimana

$a_{1}=c s_{Y} n_{Y}^{a}+c s_{X} n_{X}^{a}-n_{X} c s_{Y} n_{Y}{ }^{a-1} a-n_{Y} c s_{X} n_{X}^{a-1} a$

$a_{2}=2\left(c s_{Y} n_{Y}^{a}\right)\left(c s_{X} n_{X}^{a}\right)-2\left(c s_{Y} n_{Y}^{a}\right)\left(n_{X} c s_{Y} n_{Y}^{a-1} a\right)$

Subtitusi $n_{x}=\left(\frac{s_{Y}}{s_{X}}\right)^{\frac{1}{a-1}} n_{Y}$ ke $a_{1}$ dan $a_{2}$ sehingga diperoleh

$a_{1}=c s_{Y} n_{Y}^{a}(1-a)+c s_{X}\left(\frac{s_{Y}}{s_{X}}\right)^{\frac{a}{a-1}} n_{Y}^{a}-c s_{Y}\left(\frac{s_{Y}}{s_{X}}\right)^{\frac{1}{a-1}} n_{Y}{ }^{a} a$ $\left.a_{2}=2\left(c s_{Y} n_{y}{ }^{2 a}\right) c s_{X}\left(\frac{S_{Y}}{s_{X}}\right)^{\frac{a}{a-1}}-2\left(c s_{Y} n_{Y}{ }^{2 a}\right)\left(\frac{S_{Y}}{S_{X}}\right)^{\frac{1}{a-1}} c s_{Y} a\right)$

Akan dibuktikan $a_{1}>0$

$c s_{Y} n_{Y}{ }^{a}(1-a)+c s_{X}\left(\frac{s_{Y}}{s_{X}}\right)^{\frac{a}{a-1}} n_{Y}^{a}-c s_{Y}\left(\frac{s_{Y}}{s_{X}}\right)^{\frac{1}{a-1}} n_{Y}{ }^{a} a>0$

$\frac{s_{X}}{s_{Y}}>\frac{\left(\frac{s_{Y}}{s_{X}}\right)^{\frac{1}{a-1}} a-1+a}{\left(\frac{s_{Y}}{s_{X}}\right)^{\frac{a}{a-1}}}$

Diketahui $s_{X}<s_{Y}$

Jika $a<1$ maka nilai eigen $\left(a_{1}\right)$ akan kecil dari nol artinya titik $T_{3}$ stabil.

Jika $a>1$ maka nilai eigen $\left(a_{1}\right)$ akan besar dari nol artinya titik $T_{3}$ tidak stabil.

Akan dibuktikan $a_{2}>0$

$\left.2\left(c s_{Y} n_{y}{ }^{2 a}\right) c s_{X}\left(\frac{s_{Y}}{s_{X}}\right)^{\frac{a}{a-1}}-2\left(c s_{Y} n_{Y}^{2 a}\right)\left(\frac{s_{Y}}{s_{X}}\right)^{\frac{1}{a-1}} c s_{Y} a\right)>0$

$s_{X}\left(\frac{s_{Y}}{s_{X}}\right)^{\frac{a}{a-1}}>s_{Y}\left(\frac{s_{Y}}{s_{X}}\right)^{\frac{1}{a-1}} a$ maka

$\frac{s_{X}}{s_{Y}}>\frac{\left(\frac{s_{Y}}{s_{X}}\right)^{\frac{1}{a-1} a}}{\left(\frac{s_{Y}}{s_{X}}\right)^{\frac{a}{a-1}}}$

Diketahui $s_{X}<s_{Y}$

Jika $a<1$ maka nilai eigen $\left(a_{1}\right)$ akan kecil dari nol artinya titik $T_{3}$ stabil.

Jika $a>1$ maka nilai eigen $\left(a_{1}\right)$ akan besar dari nol artinya titik $T_{3}$ tidak stabil.

Berdasarkan analisis $T_{3}$, maka $T_{3}$ stabil jika $a>1$ dan tidak stabil jika $a<1$, dimana $s_{X}<s_{Y}$.

\section{Simulasi Kestabilan Model Matematika Dinamika Bahasa Minang dan Bahasa Indonesia}

Simulasi kestabilan titik tetap model dinamika bahasa Minang dan bahasa Indonesia dilakukan dengan membentuk trayektori dari beberapa kondisi awal yang berbeda. Dari trayektori yang dihasilkan, dapat dilihat bahwa jika kurva menuju titik tetap pada waktu tertentu maka dapat disimpulkan bahwa keberadaan titik tetap tersebut ada dan benar. Dengan kata lain, simulasi kestabilan titik tetap ini dapat digunakan sebagai alat menguji keberadaan titik tetap.

1) Simulasi Kestabilan Titik Tetap Kepunahan Bahasa Indonesia dan Bahasa Minang: Simulasi kestabilan titik tetap kepuanahan bahasa Indonesia dilakukan untuk melihat trayektori di sekitar titik tetap tersebut dengan parameter yang digunakan adalah sebagai berikut:

$s_{X}=0,4 ; c=0,5 ; a=1, b=1$

Dalam simulasi titik tetap kepunahan bahasa Indonesia, digunakan tiga nilai awal sebagai berikut:

$n_{X}(0)=0,99 ; n_{Y}(0)=0,01$

$n_{X}(0)=0,6 ; n_{Y}(0)=0,4$

$n_{X}(0)=0,7 ; n_{Y}(0)=0,3$ 
Berdasarkan parameter dan nilai awal di atas diperoleh grafik dari masing-masing kelas terhadap waktu $t$ sebagai berikut:
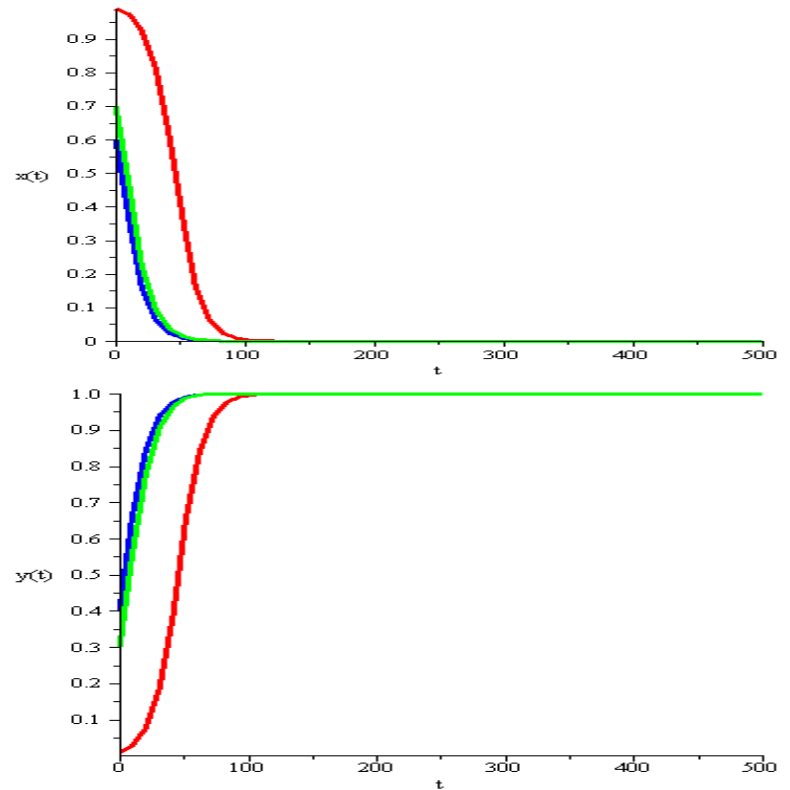

Gambar 1. Trayektori di Sekitar Titik Tetap Kepunahan bahasa Indonesia dan bahasa Minang

Dari gambar 3 di atas kurva biru, hijau, dan merah mewakili titik tetap kepunahan bahasa Indonesia dan bahasa Minang dari grafik yang bersangkutan. Arah gerak dari kurva hijau dan biru terhadap kurva biru inilah yang nantinya akan menentukan stabil atau tidaknya titik tetap bebas kepunahan bahasa pada masing-masing grafik.

Berdasarkan gambar 3, titik kepunahan bahasa Indonesia $T_{1}=(1,0)$ bersifat tidak stabil karena arah gerak dari kurva menjauhi $T_{1}$. Sedangkan untuk titik kepunahan bahasa Minang $T_{2}=(0,1)$ bersifat stabil karena arah gerak kurva mendekati $T_{2}$.

2) Simulasi Kestabilan Titik Tetap Bebas Kepunahan Bahasa : Simulasi kestabilan titik tetap bebas kepunahan bahasa dilakukan untuk melihat trayektori di sekitar titik tetap tersebut dengan parameter yang digunakan adalah sebagai berikut:

Kasus 1: $a, b<1$ dimana $a=b$.

$s_{X}=0,4 ; c=0,5 ; a=0,2 ; b=0,2$

Dalam simulasi titik tetap bebas kepunahan bahasa, digunakan tiga nilai awal sebagai berikut:

$n_{X}(0)=0,65 ; n_{Y}(0)=0,35$

$n_{X}(0)=0,71 ; n_{Y}(0)=0,29$

$n_{X}(0)=0,75 ; n_{Y}(0)=0,25$

Berdasarkan parameter dan nilai awal di atas diperoleh grafik dari masing-masing kelas terhadap waktu $t$ sebagai berikut:
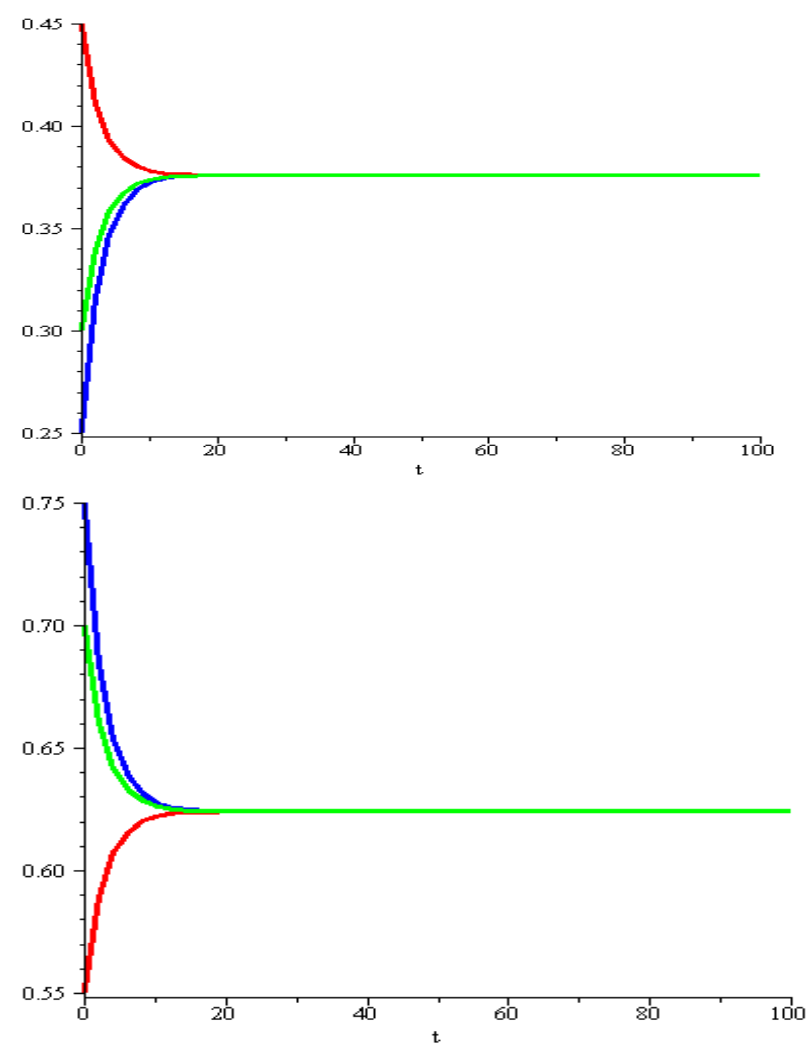

Gambar 2. Trayektori di Sekitar Titik Tetap Bebas Kepunahan jika $a, b<1$

Titik tetap kepunahan bahasa Indonesia $T_{3}=$ $\left(\left(\frac{s_{Y}\left(n_{Y}\right)^{b-1}}{s_{X}}\right)^{\frac{1}{a-1}}, n_{Y}\right)$ Jika disubtitusikan parameter diatas maka diperoleh $T_{3}=(0.375,0.625)$. Dari gambar 5 dapat dilihat arah gerak kurva sama-sama mendekati titik tetap $T_{3}$. Sehingga titik tetap $T_{3}$ bersifat stabil, maka dapat disimpulkan bahwa untuk waktu yang sangat lama bahasa Minang dan bahasa Indonesia dapat hidup berdampingan jika tingkat volatility kedua bahasa rendah. Artinya kecendrungan perubahan frekuensi bertutur bahasa lebih rendah dari kondisi netral dan kedua bahasa memiliki ketahanan yang lebih besar untuk mengubah keadaan. Sehingga sulit untuk terjadi pergeseran bahasa.

Kasus 2: $a, b>1$ dimana $a=b$.

$s_{X}=0,4 ; c=0,5 ; a=2 ; b=2$

Dalam simulasi titik tetap bebas kepunahan bahasa, digunakan tiga nilai awal sebagai berikut:

$n_{X}(0)=0,8 ; n_{Y}(0)=0,2$

$n_{X}(0)=0,7 ; n_{Y}(0)=0,3$

$n_{X}(0)=0,55 ; n_{Y}(0)=0,45$

Berdasarkan parameter dan nilai awal di atas diperoleh grafik dari masing-masing kelas terhadap waktu $t$ sebagai berikut: 

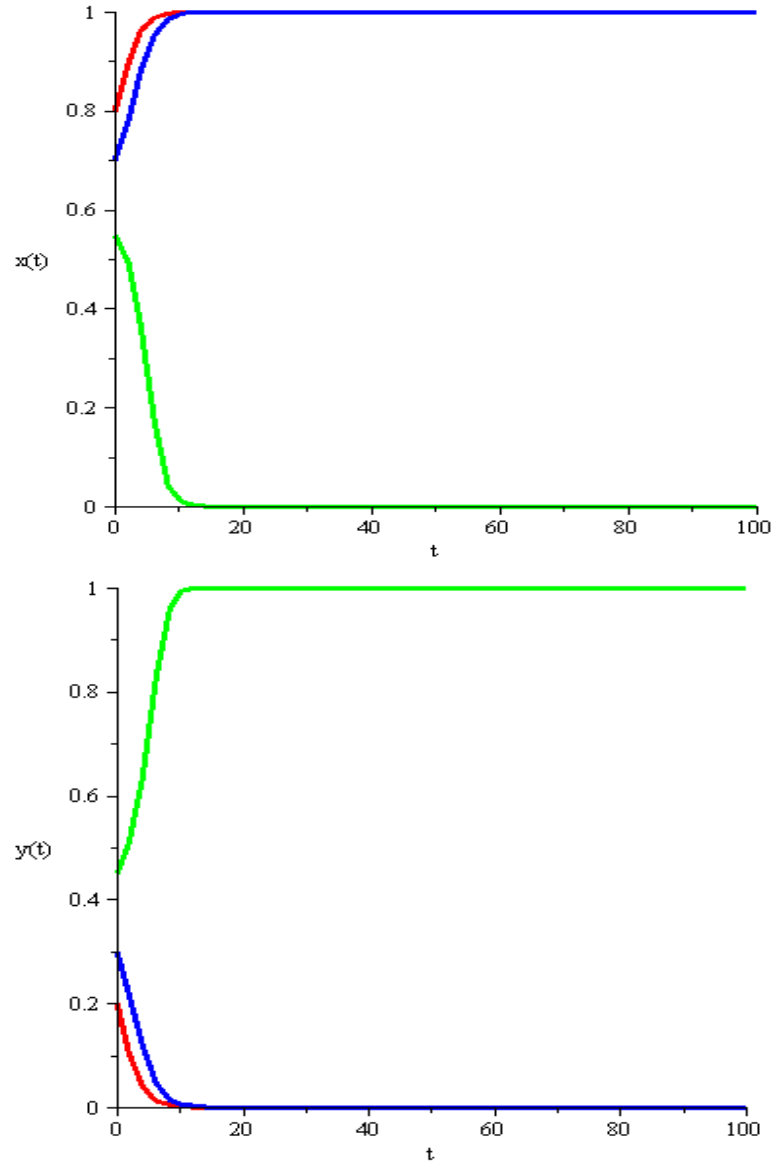

Gambar 3. Trayektori di Sekitar Titik Tetap Bebas Kepunahan jika $a, b>1$

Titik tetap kepunahan bahasa Indonesia $T_{3}=$ $\left(\left(\frac{s_{Y}\left(n_{Y}\right)^{b-1}}{s_{X}}\right)^{\frac{1}{a-1}}, n_{Y}\right)$ Jika disubtitusikan parameter diatas maka diperoleh $T_{3}=(0.6,0.4)$. Dari gambar 5 dapat dilihat bahwa arah gerak kurva menjauhi titik tetap $T_{3}$. Sehingga titik tetap $T_{3}$ bersifat tidak stabil, maka dapat disimpulkan bahwa untuk waktu yang sangat lama bahasa Minang dan bahasa Indonesia dapat hidup berdampingan jika tingkat volatility kedua bahasa tinggi. Artinya perubahan frekuensi bertutur bahasa lebih besar dari kondisi netral sehingga akan sering terjadi pergeseran bahasa.

\section{Interpertasi Model Matematika Dinamika Bahasa Minang dan Bahasa Indonesia}

Berdasarkan pembahasan diatas, dapat diketahui bahwa ada tiga titik tetap. Titik tetap pertama yaitu titik kepunahan bahasa Indonesia dimana $T_{1}=(1,0)$. Artinya untuk waktu yang sangat lama semua orang akan bertutur menggunakan bahasa Minang dan akan terjadi kepunahan bahasa Indonesia. Namun, kondisi ini tidak akan bertahan lama. Karena jika ada individu yang bertutur menggunakan bahasa Indonesia (frekuensi bahasa Indonesia tidak nol) maka bahasa Indonesia tidak akan punah.

Titik tetap kedua adalah titik tetap kepunahan bahasa Minang dimana $T_{2}=(1,0)$. Artinya untuk waktu yang sangat lama semua orang akan bertutur menggunakan bahasa Indonesia dan akan terjadi kepunahan bahasa Minang. Artinya jika ada individu yang bertutur menggunakan bahasa Minang (frekuensi bahasa Minang tidak nol) maka bahasa Minang suatu saat akan tetap punah.

Sedangkan titik tetap ketiga adalah titik bebas kepunahan dimana $T_{3}=\left(\left(\frac{s_{Y}\left(n_{Y}\right)^{b-1}}{s_{X}}\right)^{\frac{1}{a-1}}, n_{Y}\right)$. Kondisi ini merupakan kondisi yang paling baik dimana kedua bahasa dapat hidup berdampingan. Titik ini bersifat stabil jika tingkat volatility kedua bahasa rendah. Artinya kedua bahasa memiliki ketahanan yang lebih besar, sehingga tidak terjadi pergeseran bahasa. Tapi, titik ini bersifat tidak stabil jika tingkat volatility kedua bahasa besar. Artinya perubahan frekuensi bertutur bahasa lebih besar dari kondisi netral sehingga akan sering terjadi pergeseran bahasa.

Suatu bahasa akan terancam punah jika tingkat volatility bahasa tinggi. Artinya perubahan frekuensi bertutur bahasa lebih besar dari kondisi netral sehingga akan sering terjadi pergeseran bahasa. Bahasa terancam punah karena berawal dari masyarakat minang itu sendiri. Semakin berkurang menggunakan bahasa Minang dalam berkomunikasi, pengabaian bahasa minang sebagai bahasa Ibu dalam keluarga, usaha merawat identitas etnik bahasa Minang kurang, dan menganggap bahasa Minang tidak penting lagi.

Hal yang harus dilakukan adalah memiliki sikap positif dimana sikap ini dapat ditunjukan dengan kesetiaan bahasa untuk mendorong masyarakat mempertahankan bahasanya, dan apabila perlu mencegah adanya pengaruh bahasa lain. Selain itu, sikap kebanggaan bahasa yang mendorong masyarakat mengembangkan bahasanya dan menggunakannya sebagai lambang identitas dan kesatuan masyarakat. Setelah itu, status sosial dan ekonomi bahasa juga dikontrol dengan meangkat posisi sebuah bahasa menjadi bahasa yang bernilai ekonomis. Salah satu cara yang dapat dilakukan adalah misalnya dalam hal pendidikan, saat pendidikan sekolah dasar sudah diajarkan bahasa Minang. Tetapi kenyataannya, saat ini sudah tidak diajarkan lagi mata pelajaran Budaya Alam Minangkabau. Dalam hal pekerjaan, sedikit lulusan sastra Minangkabau karena merasa tidak akan mendapat pekerjaan setelah lulus. Padahal, jika daerah kita melestarikan bahasa Minang dan sering melakukan seminar mengenai bahasa Minang, pasti kita akan perlu seorang ahli bahasa Minang. Selain itu, pelestarian bahasa Minang dapat juga dilakuakan berupa penjualan produk yang menggunakan bahasa Minang seperti baju, tas, stiker, dan sebagainya.

Oleh karena itu, bahasa pasti akan mengalami perubahan dan perkembangan dari waktu ke waktu. Dinamika ini akan 
terjadi karena adanya faktor-faktor yang mempengaruhi. Dilihat dari frekuensi bertutur, status sosial ekonomi bahasa, dan tingkat volatility suatu bahasa. Jika faktor faktor diatas tidak dapat dikontrol, pastilah bahasa akan mengalami pergeseran.

\section{SIMPULAN}

Dinamika bahasa dipengaruhi oleh frekuensi penutur suatu bahasa $\left(n_{X}\right.$ dan $\left.n_{Y}\right)$, tingkat pergeseran bahasa $\left(P_{Y X}\right.$ dan $\left.P_{X Y}\right)$, tingkat status sosial ekonomi bahasa $\left(s_{X}\right.$ dan $\left.s_{Y}\right)$, tingkat interaksi $(c)$, tingkat volatility bahasa Minang $(a)$ dan tingkat volatility bahasa Indonesia (b). Agar kedua bahasa dapat hidup berdampingan maka tingkat volatility kedua bahasa harus rendah. Artinya kecendrungan perubahan frekuensi bertutur bahasa lebih rendah dari kondisi netral dan kedua bahasa memiliki ketahanan yang lebih besar sehingga sulit untuk terjadi pergeseran bahasa.
Upaya yang dapat dilakukan agar kedua bahasa dapat hidup berdampingan yaitu dengan mengurangi kecendrungan perubahan frekuensi bertutur kedua bahasa seperti membudayakan bahasa Minang dan bahasa Indonesia dalam ranah apapun. Selain itu juga dengan mengontrol status sosial dan ekonomi kedua bahasa.

\section{REFERENSI}

[1] Cain, John W., dan Reynold, Angela M. Ordinary and Partial Differential Equation: An Introduction to Dynamical Systemd. Virginia Commonwealth University

[2] Chaer, Abdul., dan Leonie Agustina. 2002. Sosiolinguistik Perkenalan Awal. Jakarta: Rinneka Cipta.

[3] Fishman, J.A. (Ed.). 1968. Reading in the Sociology of Language. Den Haag-Paris : Mouton.

[4] Kamus Besar Bahasa Indonesia Edisi Ketiga.2005. Jakarta : Balai Pustaka

[5] Liu, Yanxin. 2009. Modelling Language Competition.

[6] Rahma, Nadiatur. 2016. Model Matematika Dinamika Bahasa Minang dan Bahasa Indonesia. Universitas Negeri Padang. 